\title{
The Implementation of Inclusive Education in Arabic Learning for Blind تنفيذ التربية الشاملة في تعليم اللغة العربية للتلاميذ المعاقين ضعف البصر /Students
}

\author{
Maftuhatur Rohmah \\ Independen \\ maftuhaturohmah10@gmail.com
}

\begin{abstract}
Every citizen has the right to education. Likewise, the right to teach Arabic, which is one of the subjects taught in schools, is not only taught to ordinary students, but also to students with physical limitations. The purpose of this study was to describe the implementation of Arabic language learning in an inclusive class. Learning Arabic in an inclusive classroom is a general class between ordinary students and students with special needs (visually impaired). In learning Arabic in an inclusive class, teachers experience difficulties because they do not have special teaching skills in an inclusive class. The readiness of teachers in preparing teaching materials that can be accessed by blind students is the key to the success of learning Arabic for blind students.
\end{abstract}

Keywords : Inclusive Education, Arabic Language, Blind Student.

\section{ABSTRAK}

Setiap warga negara berhak atas pendidikan. Demikian juga, hak untuk mengajar bahasa arab, yang merupakan salah satu mata pelajaran yang diajarkan di sekolah, tidak hanya diajarkan kepada siswa biasa, tetapi juga untuk siswa keterbatasan fisik. Tujuan dari penelitian ini adalah untuk menggambarkan pelaksanaan pembelajaran bahasa arab di kelas inklusif. Pembelajaran Bahasa Arab di kelas inklusif adalah kelas umum antara siswa biasa dan siswa dengan berkebutuhan khusus (tunanetra). Dalam pembelajaran Bahasa arab di kelas inklusif, guru mengalami kesulitan karena mereka tidak memiliki kemampuan mengajar khusus di kelas inklusif. Kesiapan guru dalam menyiapkan bahan ajar yang dapat diakses oleh siswa tunanetra menjadi kunci kesuksesan pembelajaran Bahasa arab bagi siswa tunanetra.

Kata Kunci : Pendidikan Inklusif, Bahasa Arab, Siswa Tunanetra.

المقدمة

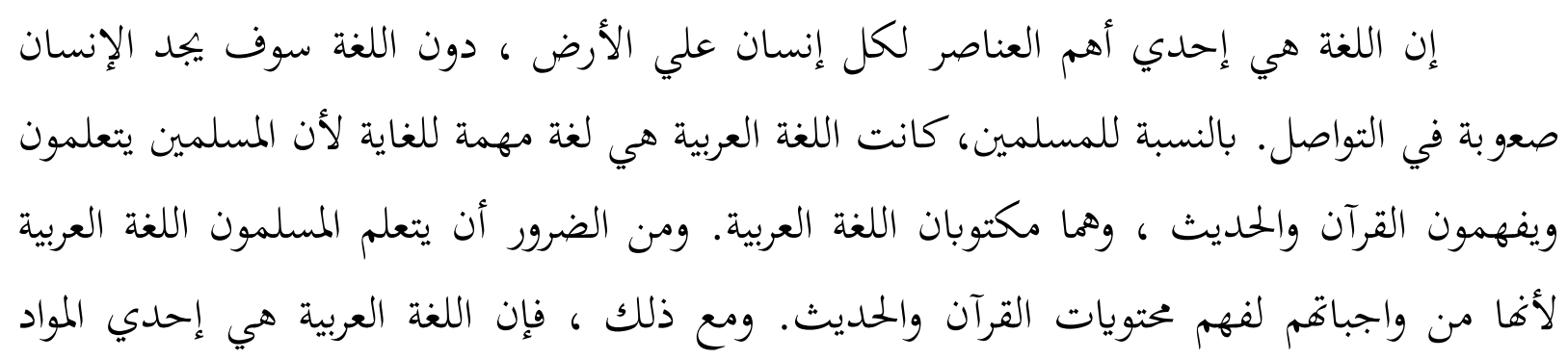


الدراسية لا يتعلمها الإنسان العادي فقط بل يتعلمها ايضا الإنسان غير العادي له عوائق في التعليم

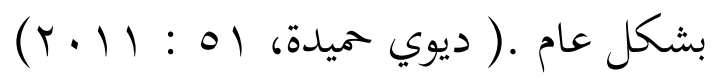

التعليم الشامل تربية يشارك كل التلاميذ فيها معا في جو وعملية التعليم على خدمة لائقة ومناسبة بحاجيات فردية للتلاميذ بدون تفريق بينهم من خلفية قبائلية و أحوال اجتماعية و اقتصادية و سياسية و عائلية و لغوية و جغرفية و مسكن و جنس و دين وفرق

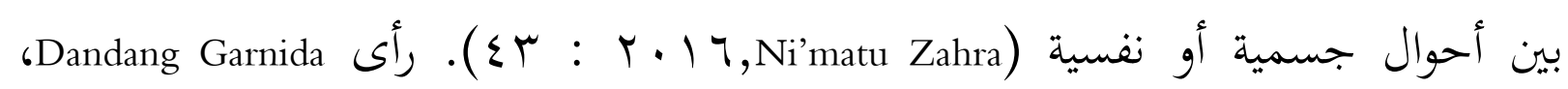

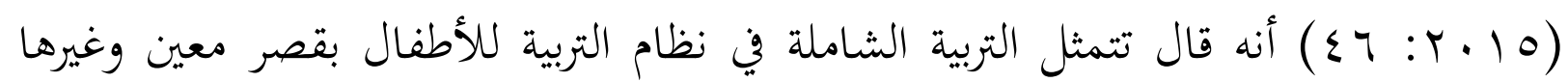
حيث يوحد بدون نظر في قصر من أنفسهم. إن من مزايا في اندونيسيا هو وجود التعليم الشامل. التعليم الشامل هو تعليم ينظم إمكانية

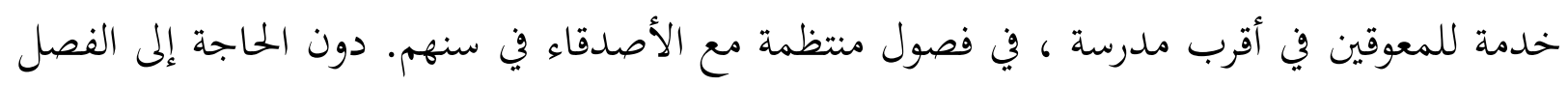

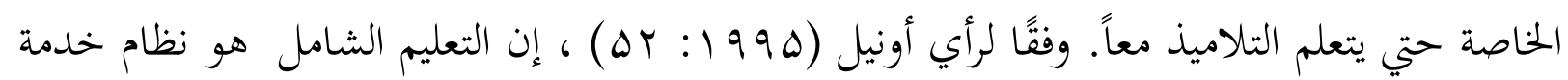
تعليمية يتطلب من التلاميذ ذوي الاحتياجات الخاص أن يدرسوا في أقرب المدارس في الفصول العادية مع الأصدقاء من نفس العمر.

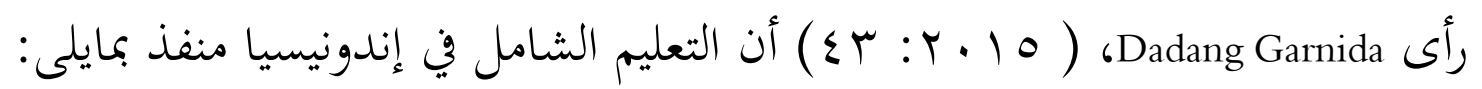
ا ـ إعطاء فرصة وسيعة إلى جميع التلاميذ (محا يكون فيها من التميذذ الذين حاجة خاصة) لنيل التعليم الائقة المناسبة لحاجتهم. Y . مساعة تسريع برنامج التعليم الواجب الأساسي. ץ. مساعدة ترقية نوعية تربوية في المستوى الإبتدائي و متوسطة بتقصير التصريف. ـ ـ جعل نظام التربية التي تعتزز بمتفرقات و دون مميز و لطيف في تعليم. تلبية الأمانة من القنون الأساسيةه \9 1 خصوصا في فصل بس أية ا :؛ لكل مواطن حق في الحصول علي التعليم" , وأية r : "كل مواطن ملنم باتباع التعليم الأساسي و تضطر

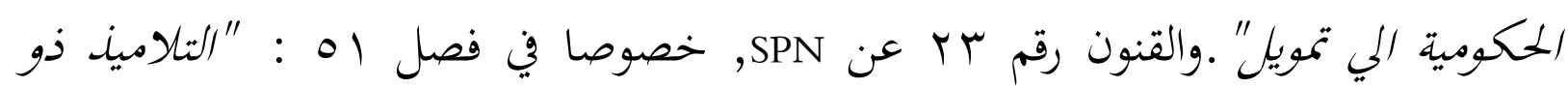


الإعاقة الجسلية والعقلية علي قلم المساواة من فرص إمكانية الحصول علي التعليم العادي و غبر العادي"

حسب القانون رقم · r من عام ب . . ب بشأن نظام التعليم الوطني ، التعليم الخاص هو تنفيذ التعليم للتلاميذ ذوي الإعاقة أو التلاميذ الذين لديهم ذكاء غير عادي. يقام هذا التعليم على أساس شامل أو في شكل وحدات تعليمية خاصة على مستوى التعليم الابتدائي والثانوي.

والتالي، تمثل التعليم الشامل في نظام التربية التي لا تفرق بين اللخلفية للتلاميذ بقصر

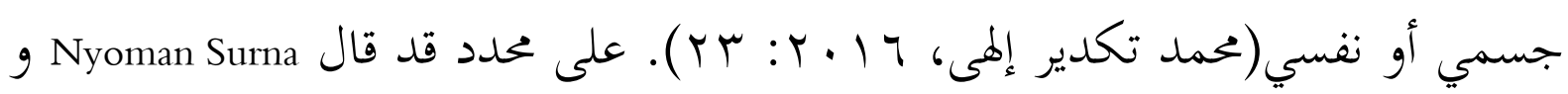
Olga D Pandeirot حاجة خاصة باستخدام مدخل تعليمي كلي مطابق نظمي. ولذالك، أن تقر إعادة التركيب في المدرسة حتي تصير بها جماعة داعمة لقضية حاجيات لتلميذ. والمعنى الأخر توفرت في التعليم الشامل موارد تعليمية غانية ودفاعة من جميع أطراف متعلقة مند التلميذ والمعلمين والوالدين والجمتمع وغيرها.

تنفيذ التعليم الثامل ليس صالحًا لتعليم المواد العامة فحسب، بل ينفيذ أيضا لجميع الدراسية ، بما في ذلك تعليم اللغة العربية. اللغة العربية مهمة للتعليم ، لأن اللغة العربية هي لغة القرآن. من خلال إتقان اللغة العربية ، يمكن للمسلمين فهم ححتويات القرآن والحديث. لذالك ك يتم تشجيع جميع المسلمين على تعليم اللغة العربية ، بما في ذلك للتلاميذ الذين يكتاجون إلى التعليم الشامل. يعد هذا التعليم الشامل المطبق في المدرسة العالية الإسلامية الحلكومية أحد مؤسسات التعليم الرسمي التي طبقت التعليم الشامل الذي يجمع التلاميذ ذوي الاحتياجات اللاصة (المعاقين) مع التلاميذ العاديين عمومًا للتعلم معًا. في هذه المدرسة يكصلون على نفس الحقوق التي يتمتع بها الآخرون ، الذين هم طبيعيون في الحصول على التعليم والتعليم. 
بعد مالاحظت الباحثة هذا التعليم الشامل وجدت ان في المدرسة العالية الإسلامية الحكومية بكاتين تعليما شاملا. لكل مواطن حق في التربية. وكذلك حق في تعليم اللغة العربية التي هي إحدى من المواد التي تدرس في المدرسة، لا تدرس للتلاميذ العاديين فقط، ولكن تدرس أيضا للتلاميذ المعاقين ضعف البصر. التعليم في الفصول الشاملة هو فصل مشترك بين التلاميذ العاديين والتلاميذ ذوي الاحتياجات الخاصة (ضعف البصر). في التعليم الشامل يواجه المعلمون صعوبات لأغم لا يملكون بقدرات خاصة في التدريس في الفصول الشاملة. كانت المدرسة العالية الحكومية الإسلامية كلاتين تملك القرارات في تنفيد التعليم الشامل ولكن ليس لما معلم خاص لتعليم التلاميذ المعاقين. فإن التعليم اللغة العربية للتلاميذ العاديين والمعاقين علي سبيل السواء من حيث وسائله التعليمية . حاجة ملحة الي الإستراتيجيات الخاص في التعليم اللغة العربية للتلاميذ المعاقين.

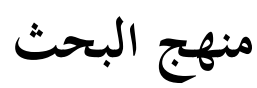

هذا البحث من بحث وصفي، يعني البحث الذي ينتج بيانات وصفية مكتوبة وشفوية من الموضوع والمخبرين وكذلك المكان الذي سيتم التحقيق فيه ومن ثم يتم تقديمه من خلال وصف البحت البيانات في شكل كلمات أو صور دون أي بيانات حساب أو قياس. يجري هذا البحث في المدرسة العالية الحكومية بككلاتين لأن المؤسسة هي مؤسسة تعليمية تنفذ تطبيق التعليم الشامل في تعليم اللغة العربية

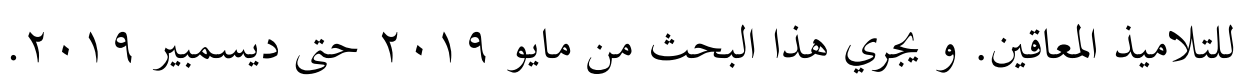

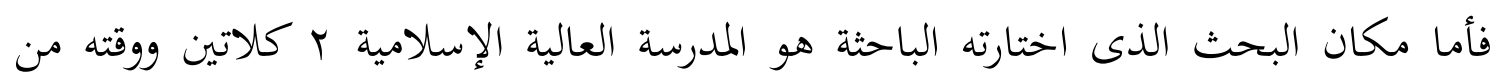

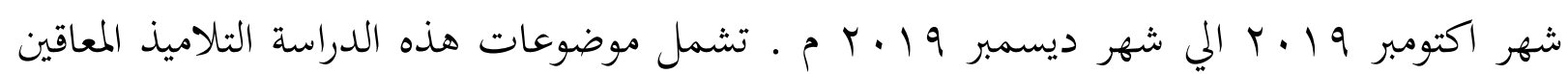
ضعف البصر في الصف العاشر من هذه المدرسة. في حين أن مخبرو البحث هنا هم مدرسوا اللغة

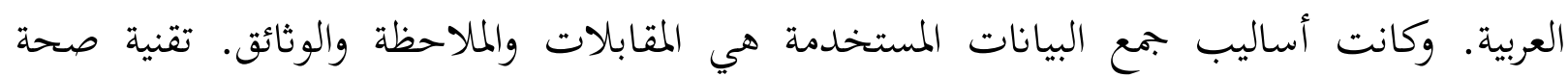
البيانات المستخدمة هي تثليث المصدر والطريقة. في تحليل البيانات باستخدام نموذج تفاعلي هو تقديم البيانات ، والحد من البيانات واستخلاص النتائج. 


\section{نتائج البحث}

مفهوم التعليم الثامل و أهدافه

التعليم الشامل تربية يشارك كل التلاميذ فيها معا في جو وعملية التعليم على خدمة لائقة

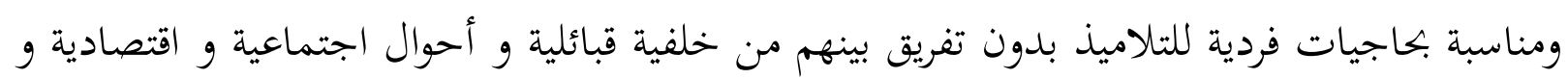

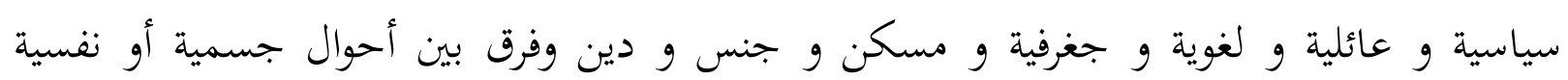

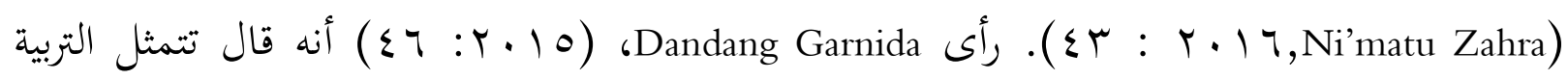
الشاملة في نظام التربية للأطفال بقصر معين وغيرها حيث يوحد بدون نظر في قصر من أنفسهم.

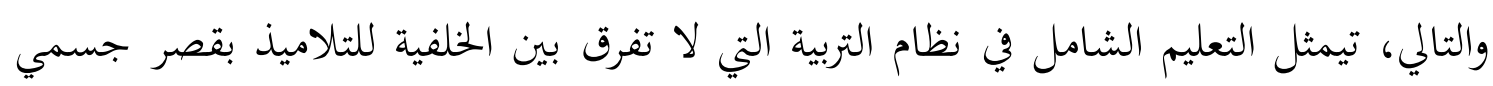

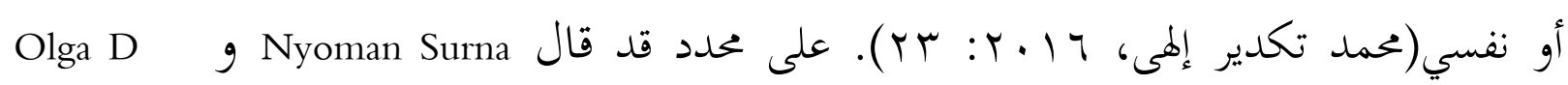
Pandeirot

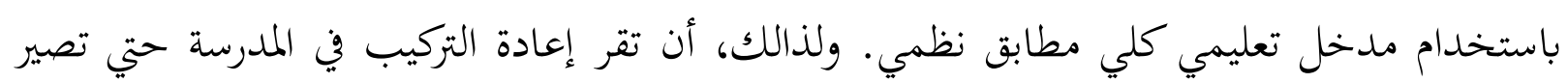
هما جماعة داعمة لقضية حاجيات لتلميذ. والمعنى الأخر توفرت في التعليم الشامل موارد تعليمية غانية ودفاعة من جميع أطراف متعلقة مند التلميذ والمعلمين والوالدين والمجتمع وغيرها.

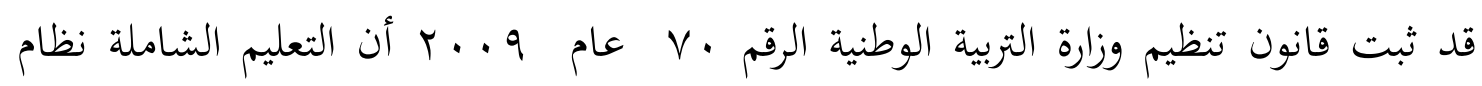

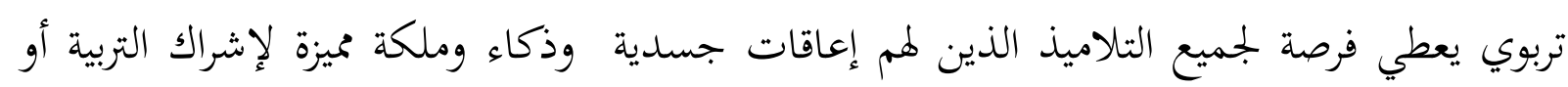

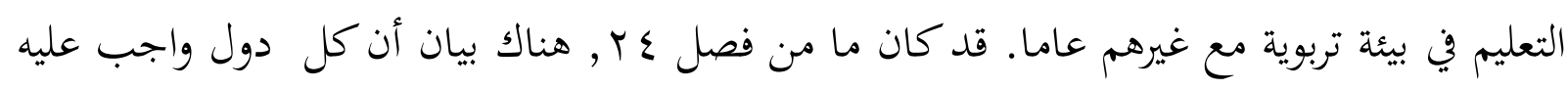

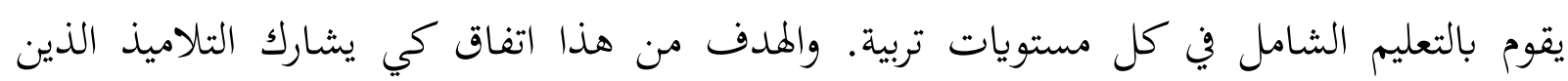

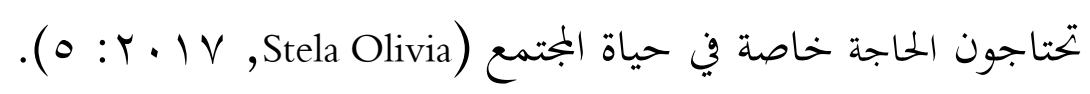

بناء على ما سبق أن يستنتج أن التعليم الشامل نشاط تربوي جعل لمساعدة الحكومة في قضية الواجبة للتعليم عند التلاميذ الذين يحتاجون حاجة خاصة، حيث يتشاركون عليها للتعليم مع لآخرين

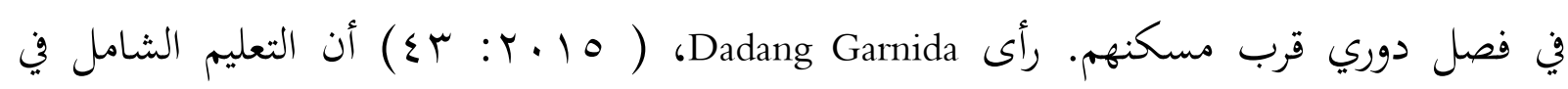

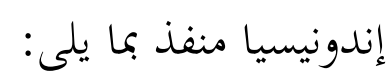

إعطاء فرصة وسيعة إلى جميع التلاميذ (ما يكون فيها من التلميذذ الذين حاجة خاصة) لنيل التعليم الائقة المناسبة لحاجتهم. 


$$
\text { مساعة تسريع برنامج التعليم الواجب الأساسي }
$$

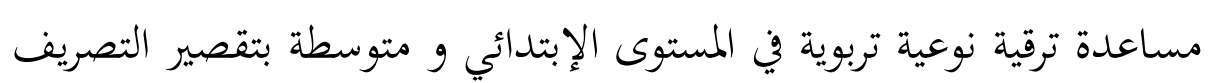

$$
\text { جعل نظام التربية التي تعتزز بمتفرقات و دون ميز و لطيف في تعليم }
$$

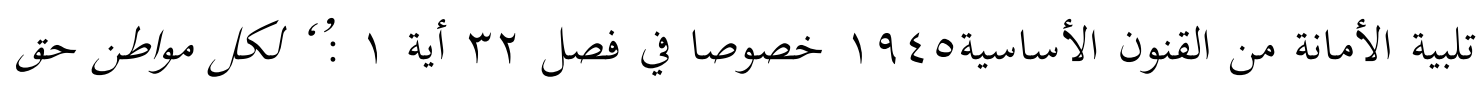

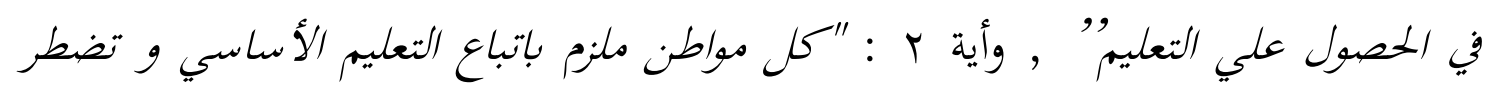

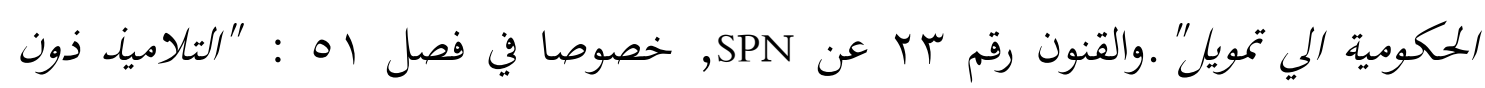
الإعاقة الجسلدية والعتلية علي قدم المساواة من فرص إمكانية الحصول علي التعليم العادي و غير العادي" .

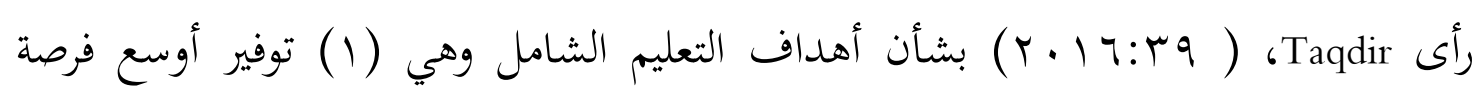
لجميع التلاميذ الذين يعانون من إعاقات جسدية وعاطفية وعقلية واجتماعية أو لديهم القدرة على لحمئ

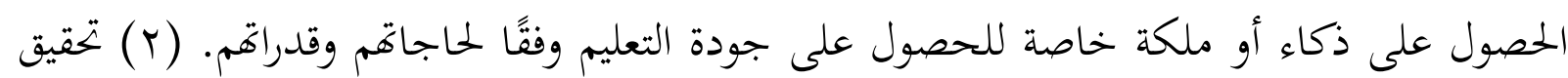

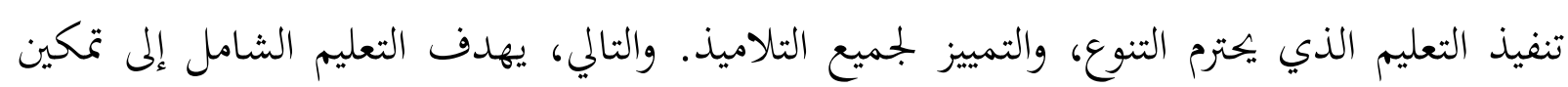
Stela (الأطفال ذوي الاحتياجات الخاصة من الحصول على حقوق تعليمية متساوية مع الأخرين $(q: r \cdot) V_{6}$ Olivia

من الشرح السابق أن يستنتج أن هدف التعليم الشامل أن يحصل التلاميذ ذو الاحتياجات الخاصة على التعليم المناسب وخلق نظام تعليمي يقدر تنوع, غير تمييزي، وصديق للتعلم. تنفيذ التعليم الشامل تتكون إدارة التعلم الشامل للأطفال ذوي الاحتياجات الخاصة من عملية تبدأ من التخطيط

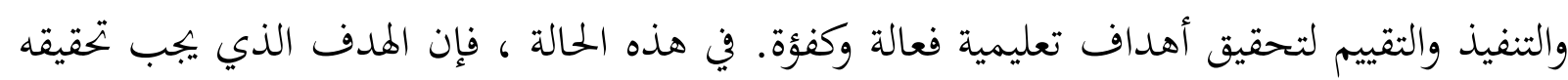
في إدارة التعليم الشامل للتلاميذ ذوي الاحتياجات الخاصة هو تحقيق التنفيذ المنصف للجين الجودة وأنظمة

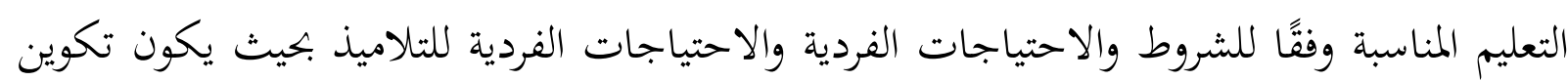

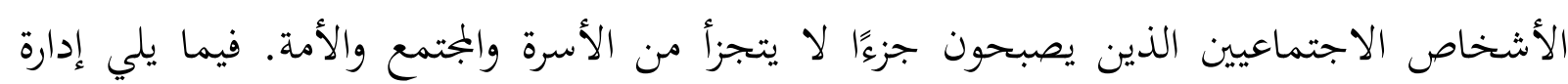
تعليم شاملة للتلاميذ ذوي الاحتياجات الخاصة بما في ذلك : ( ) التخطيط للتعليم الشامل 
قال Suryosubroto (ع . . ץ: 111) أنه عند التخطيط ، هناك إجراءات يجب اتخاذها لتحديد الأهداف والغايات التي يتم تحقيقها ، وصياغة التكتيكات والاستراتيجيات بحيث يمكن تحقيق

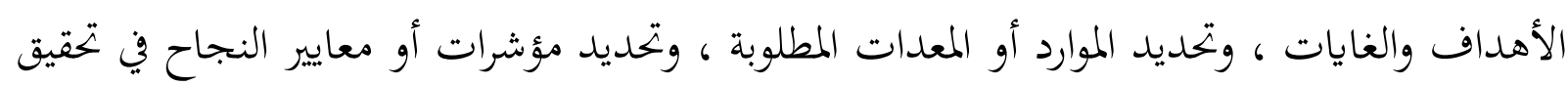
الأهداف والغايات.

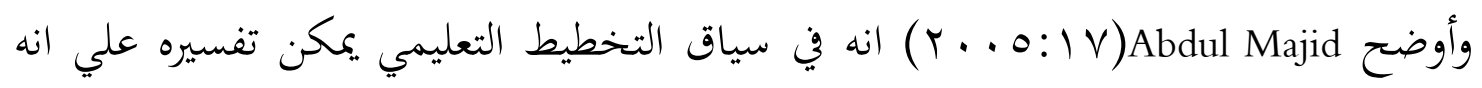

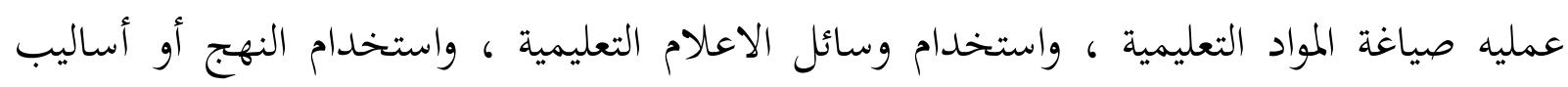
التعليم ، والتقييم في موقع حان الوقت لتحقيق هدف محدد. تخطيط التعليم هو توقع وتقدير ما سيتم القيام به في التعلم لخلق الوضع الذي يسمح لعمليه التعليم التي يمكن ان توفيم تقدم المتعلمين لتحقيق الأهداف المتوقع. وعند التخطيط للتخطيط الجيد ، يمكن تحقيق هدف التعليم بفعالية وكفاءه.

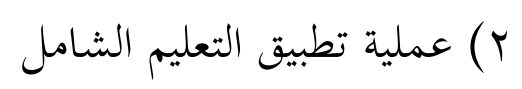

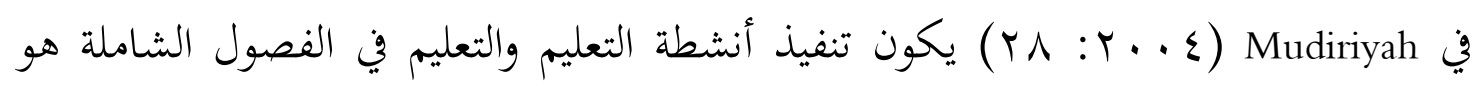
نفسه تنفيذ أنشطة التعليم والتعليم في الفصول العادية. ومع ذلك ، لأنه في الفصول الشاملة إلى الى

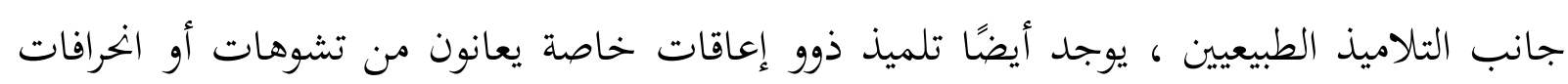
(حسية جسدية وفكرية واجتماعية وعاطفية وعصبية) مقارنة بالتلاميذ العاديين ، لذا في الأنشطة التي

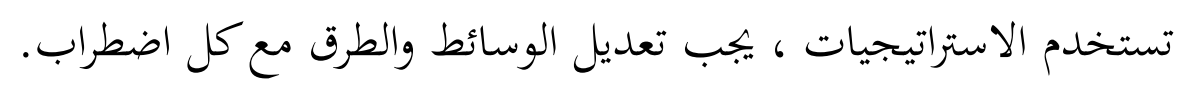

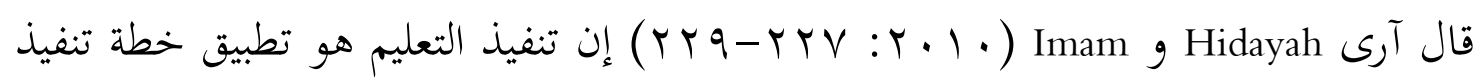
التعليم. يتضمن تنفيذ التعليم الأنشطة الأولية والأنشطة الأساسية والأنشطة الختامية. ( ) الأنشطة الأولية

إعداد التلاميذ نفسيا وجسديا للمشاركة في عملية التعلم

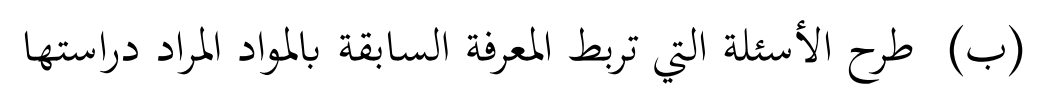

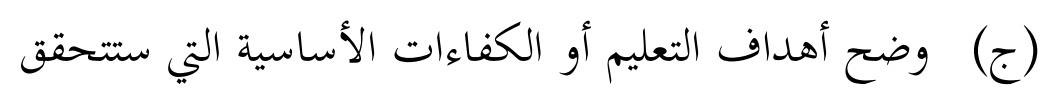

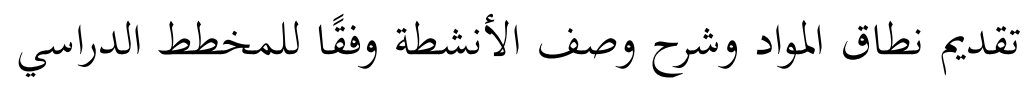

$$
\text { r) ( الأنشطة الأساسية }
$$

يعد تنفيذ الأنشطة الأساسية بمثابة عملية تعليمية لتحقيق الكفاءة الأساسية التي يتم تنفيذها بشكل تفاعلي وملهم ومتع وتحدي ، وتحفز الطلاب على المشاركة بنشاط ، وتوفر مساحة 
كافية للمبادرة ، والإبداع ، والاستقلال وفقًا للمواهب والاهتمامات والاهتمامات الجسدية والنفسية للمشاركين المتعلمين. تستخدم الأنشطة الأساسية أساليب مخصصة لخصائص التلاميذ والمواد الدراسية ، والتي يمكن أن تشمل عملية الاستكشاف والتوضيح والتأكيد. r) بإغلاق النشاط

$$
\text { مع التلاميذ و / أو أنفسهم يقدمون ملخصًا / خاتمة للدرس }
$$

(ب) (إجراء تقييمات و / أو تأملات بشأن الأنشطة التي تم تنفيذها باستمرار وبرمجتها

$$
\text { تقديم ملاحظات حول العملية ونتائج التعليم }
$$

تخطط لأنشطة المتابعة في شكل برامج تعليمية علاجية ، وبرامج إثراء ، و و / أو أو أبعائ خدمات إسداء المشورة و / أو إسناد مهام ، كلاً من المهام الفردية والجماعية وفقًا لنتائج

$$
\begin{aligned}
& \text { مخرجات تعليم التلاميذ } \\
& \text { (ه) تهـيم خطة تعليمية في الاجتماع التالي. } \\
& \text { القدرة على التعلم من المعاقين ضعف البصر }
\end{aligned}
$$

تعلم القراءة النفسية عملية معقدة، لكن القراءة بالأصابع كما يتضح من التمين صعيذ المعاقين أصعب من استخدام العيون. التلاميذ الذين يعانون من إعاقة بصرية في تعلم القراءة باستخدام طريقة

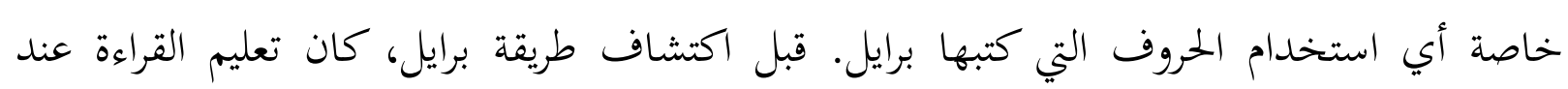

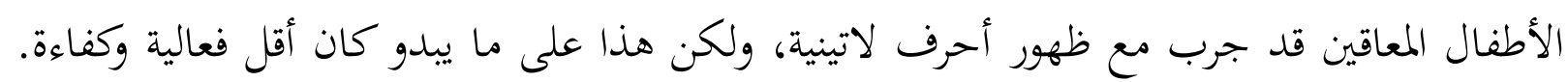
تُستخدم حروف برايل بدلاً من الحروف اللاتينية، وتتألف من نقاط يتم إنشاؤها وقراءمّا بأصابع.

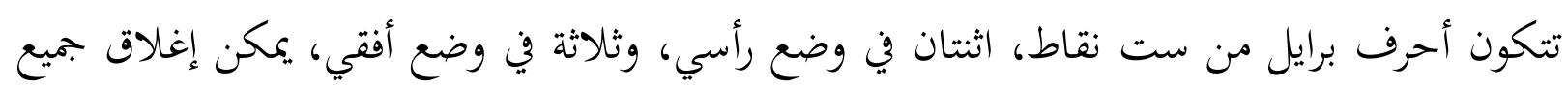

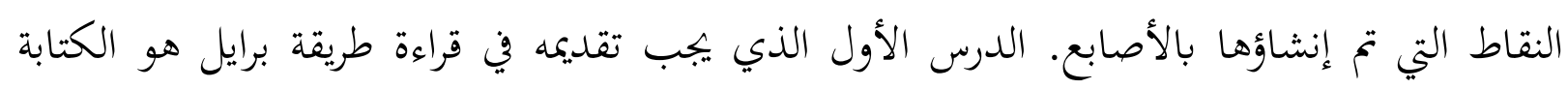

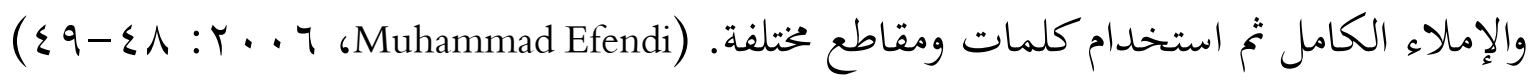

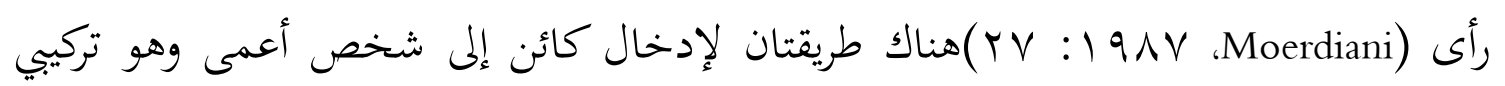
وتحليلي. في التصور التخليقي، سيتم تحليل كائن ككل باستخدام يد واحدة أو كلتا اليدين ، ثم سيتم

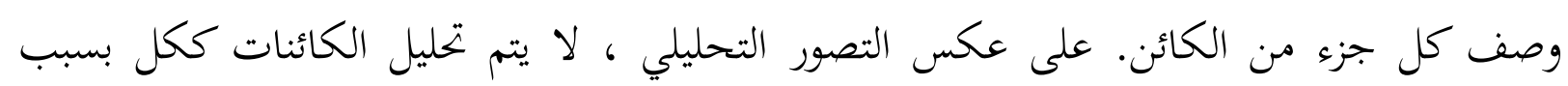


حجمها كبير جدًا أو بعيد جدًا. إذا كان كائن كبيرا أو بعيدا عن تحقيقه ، فسيتم إعطاؤهم نموذجًا أو نسخة طبق الأصل لها نفس خصائص الكائن الأصلي.

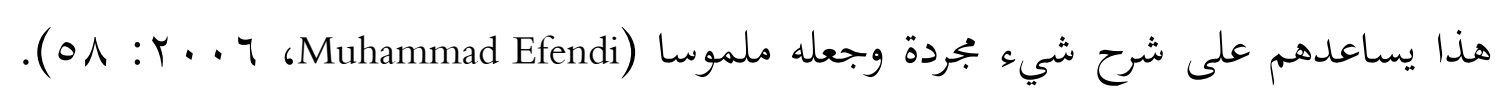
بعد إدخال كائن باستخدام التصورين التاليين، ستحدث العمليات الذهنية في أذهاهم. هذاء هو المكان

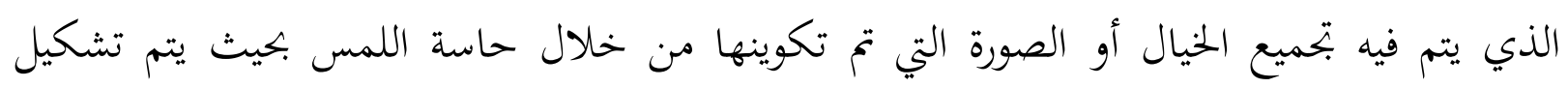

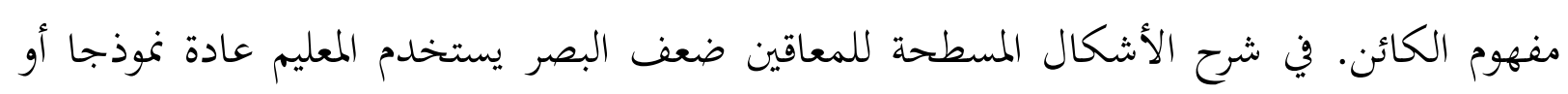

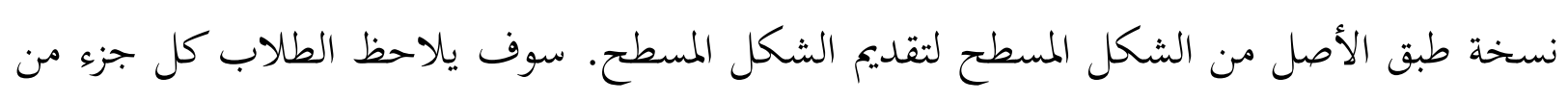

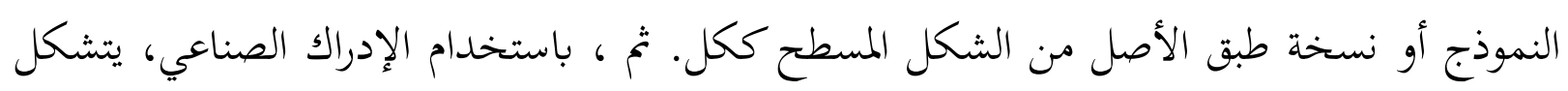
مفهوم الشكل المسطح في أذهاهم.

من المختمل أن تكون صورة كائن من جانب شخص فئ أعمى مختلفة عن تصورنا كأشخاص

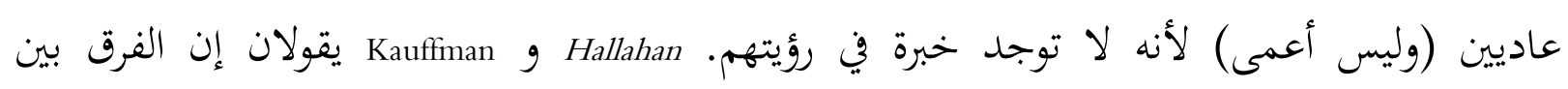

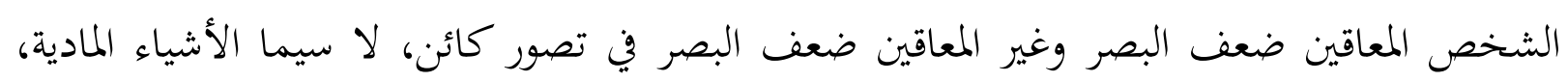

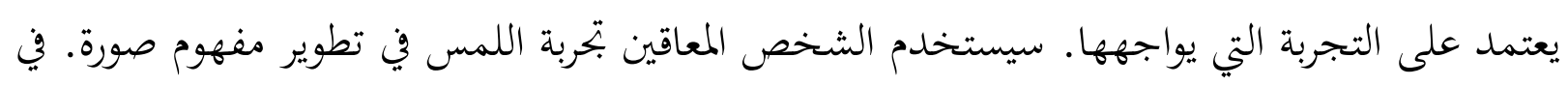

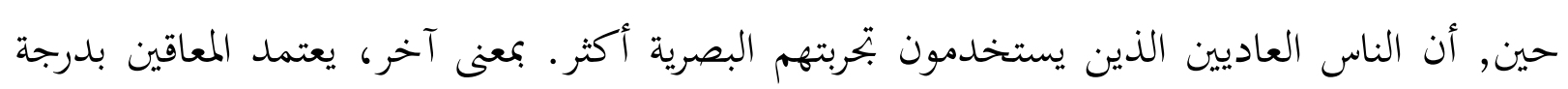

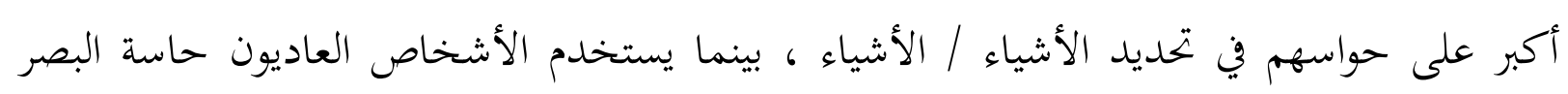
لديهم. تعليم اللغة العربية للتلاميذ المعاقين ضعف البصر يشرح هذا الفصل كيفية تنفيذ التعليم الشامل في تعلم اللغة العربية في المدرسة العالية الحكومية

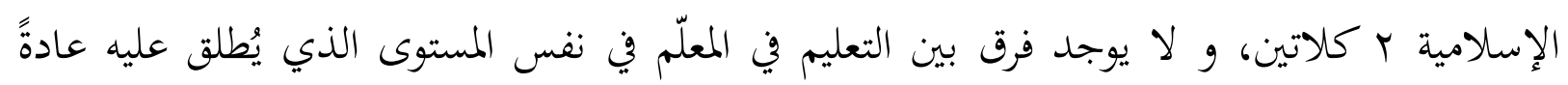

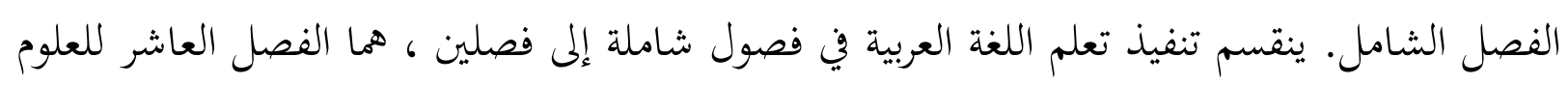

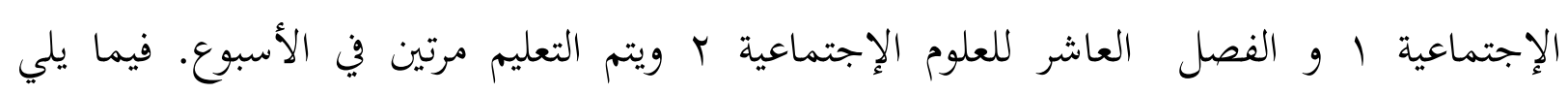
خطوات تنفيذ التعليم الشامل: ا ـ التخطيط للتعليم الشامل في تعليم اللغة العربية قبل أن تتم عملية التعليم ، هناك حاجة إلى إعداد دقيق ومخطط لتحقيق الأهداف المعاينة.

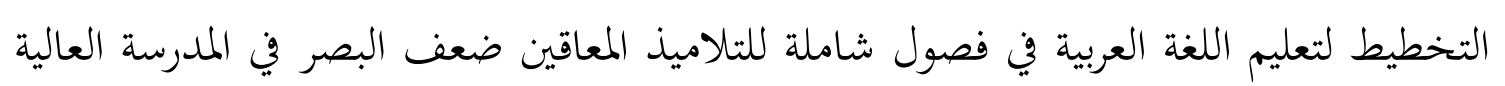


الحكومية الإسلامية r كلاتين جعلها مثالية قدر الإمكان من خلال إيلاء الاهتمام لحالات

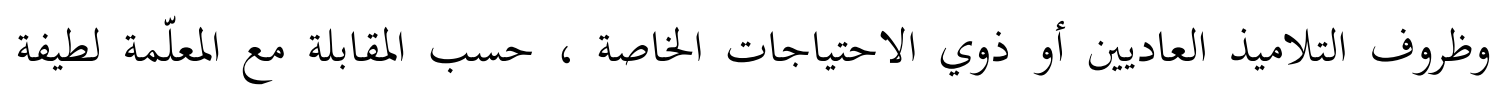

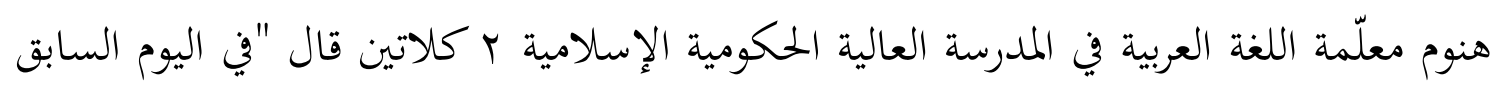

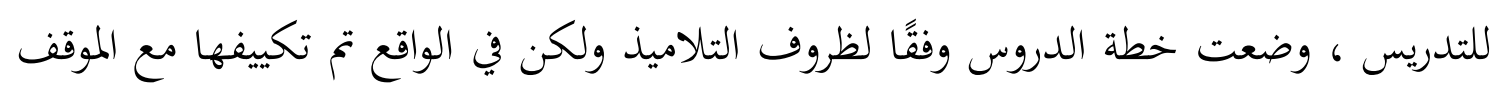

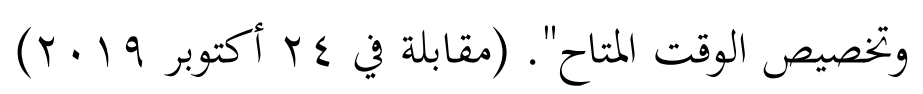

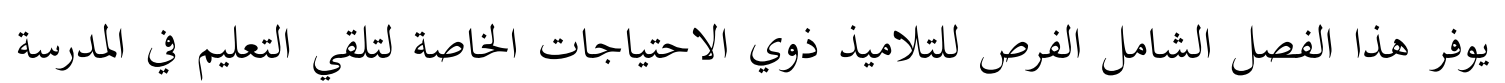

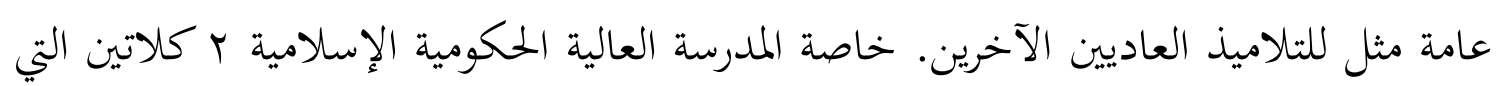

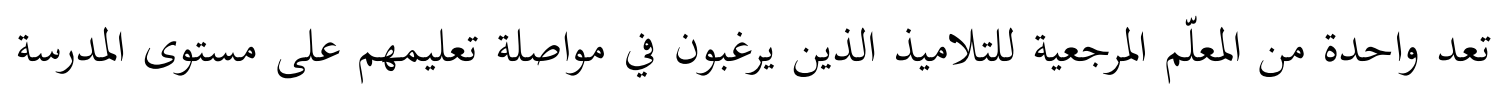

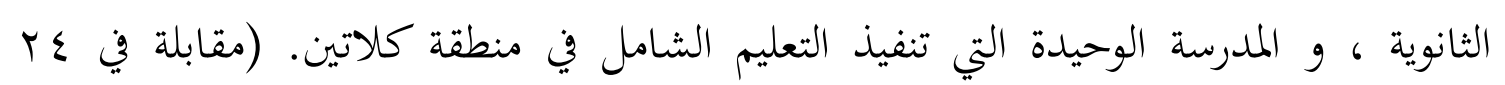

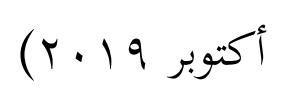

r. عملية تعليم اللغة العربية في الفصول الشاملة

كل حصة لتعليم اللغة العربية تحتاج إلى ع حصاص لكل أسبوع وفي اللقاء لمواد تعليم اللغة

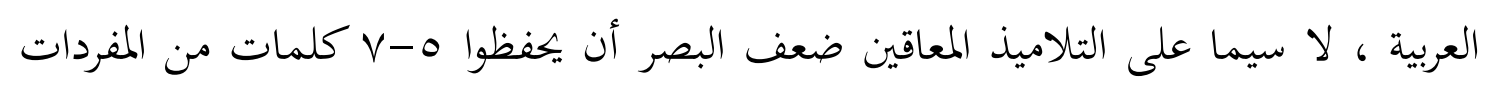

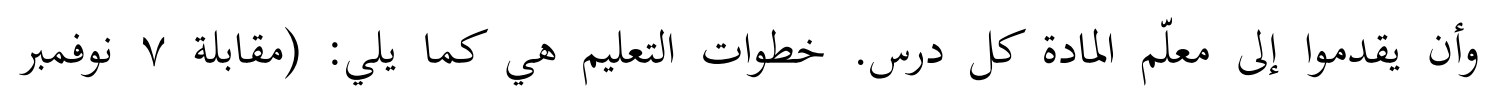
$(r \cdot 19$ الإفتتاح

عند بدء التعليم يجب على مدرسة اللغة العربية خلق ان جعلوا الطبقة مواتية بحيث يكون

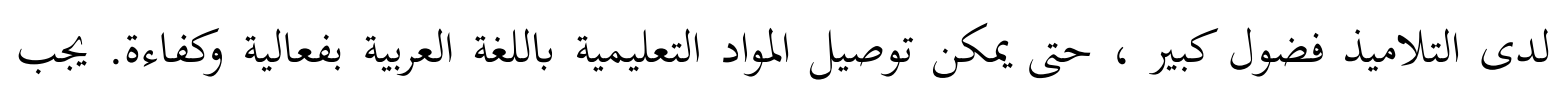

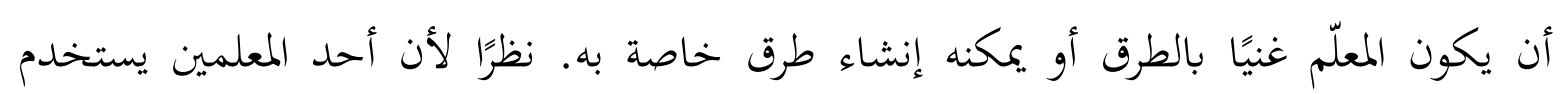

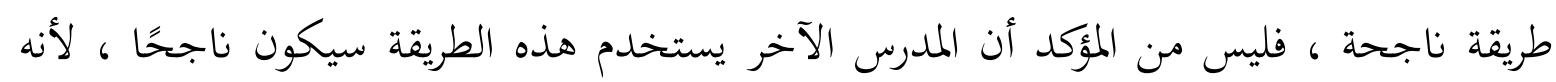

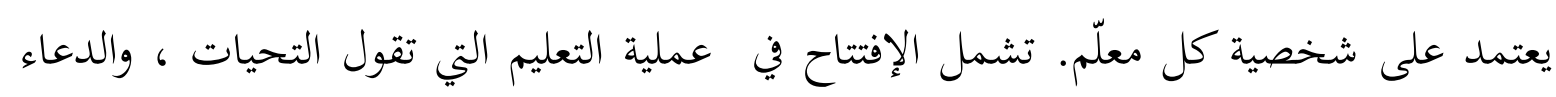
للتعلم سويًا ، وترتيب الفصل ، والسؤال عن كيفية أداة التلاميذ ، وحضور التلاميذ ، ومراجعة التهية

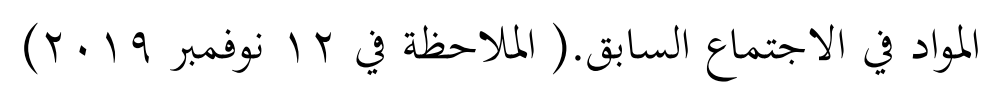


في المقدمة ترمي المعلّمة لطيفة هانوم إلى الفصل في الساعة الثاني عشر والثلاثين دقيقا بعد رنين الجرس ، ثم تقرأ السلام "السلام عليكم يا بنيا ! " فيجيب التلاميذ جهريا "وعليكم السلام يا توليا

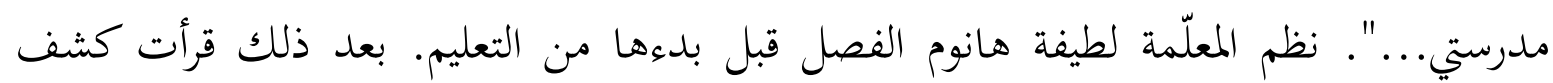
الحضور واحدا بواحد ثم قرأت مع تلاميذه الدعاء للتعليم جماعة. وبعد قراءة الدعاء سألت الحالة

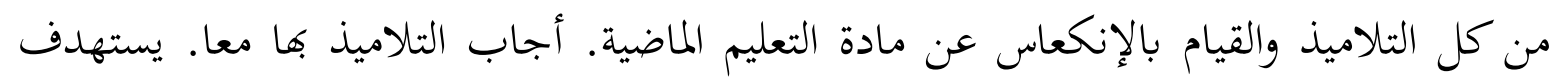

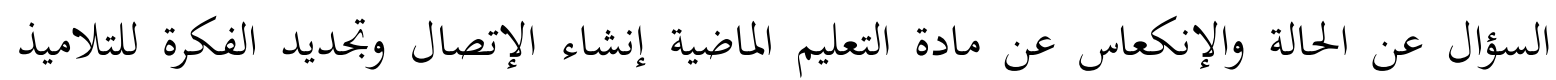
ليستمروا مادة التعليم التالية جيدا وقراة كشف الحضور معا. ب) الأنشطة الأساسية بناء على الملاحظة في تاريخ ب ا نوفمبر 9 1 ـ Y م أن الأنشطة الأساسية في التعليم إلقاء

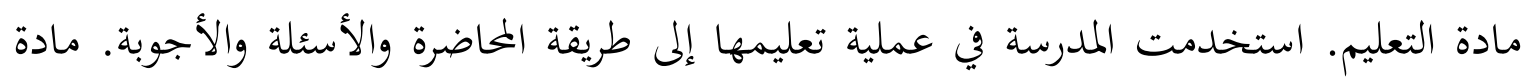
التعليم الملقية لما في الفصل العاشر من بجال العلوم الإجتماعية ا والفصل العاشر من مجال العلوم

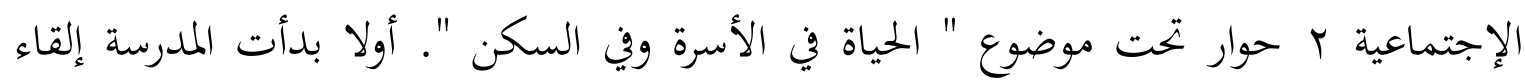
مادة التعليم في الباب الثالث عن " الحياة في الأسرة وفي السكن " على طريقة المحاضرة, بحيث الميث

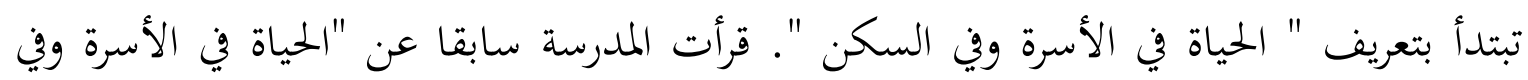
السكن" تدريجا ليستمع التلاميذ المعاقين ضعف البصر جيدا. والتلاميذ العادون يستمعون بها

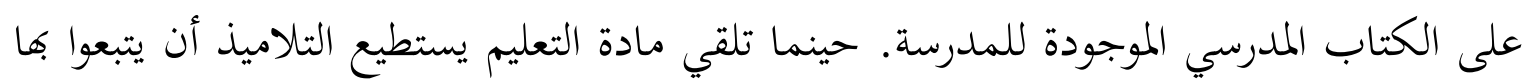

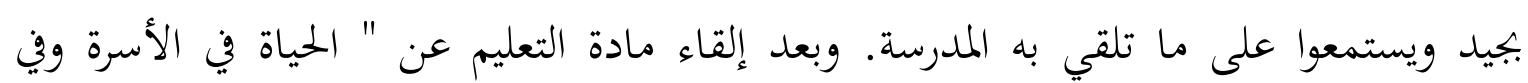
السكن " قد انتهت تشرف المعلّمة لطيفة هانوم ليتبعوا على ما تلقي به جماعة. وكان التلاميذ التهاء

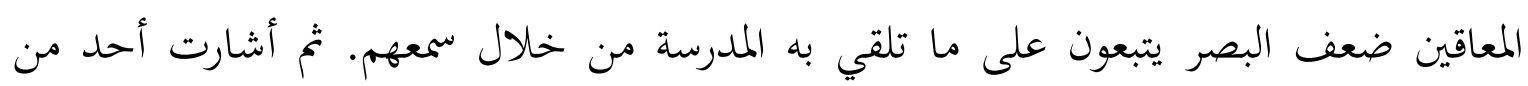
التلاميذ ليقرأ نص الحوار مع التلميذ الآخر أمام الفصل. والآخرون يستمعون به به والتلاميذ المعاقين ضعف البصر يستمعون بسمعهم. ثم أعطت المعلّمة لطيفة هانوم مهمة تربمة نص القراءة ، وقسمت المقعد لتفسيره معًا.

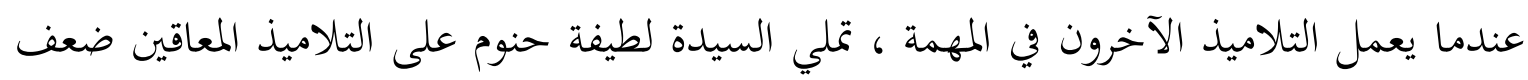

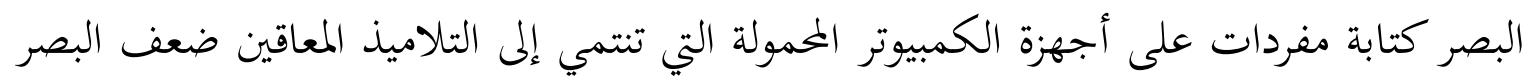


ولا يزال هناك أشخاص يستخدمون طريقة برايل ، ثم يسأل المعلّم المادة التي لم يتم فهمها بعد (braille) هناك أحد من التلاميذ المعاقين ضعف البصر سينو (Seno) وهو تلميذ الفصل العاشر من علوم

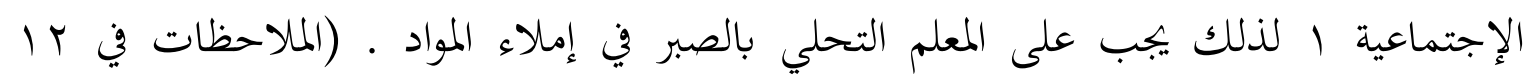

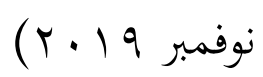
بعد الانتهاء من كل شيء ، يقوم المعلّمة بإخبار جميع التلاميذ بما في ذلك التلاميذ

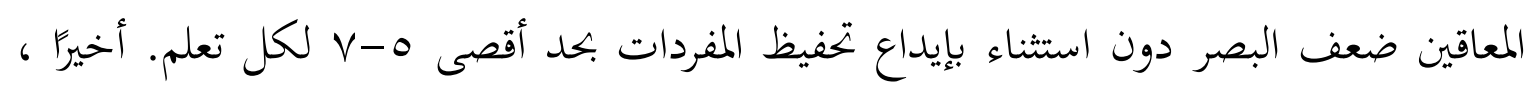
يعطي المعلّم مهمة عملية لشخصين أمام الفصل للاجتماع التالي. ج) (الإختام

عملية تعليم العربية في التعليم الشامل في الفصل العاشر من الفصل للعلوم الإجتماعية ب قد

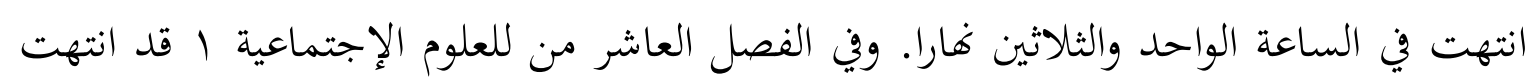

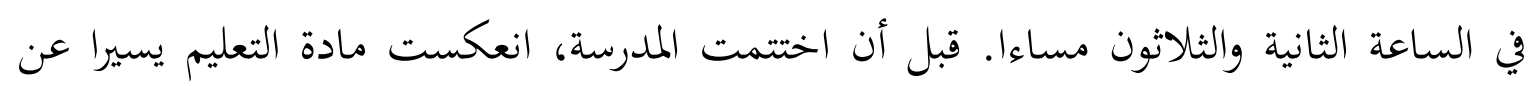
مادة التعليم التي لقت بها وإعادة النظر في الكتاب المدرسي للتلاميذ. دعت المدرسة تلاميذها

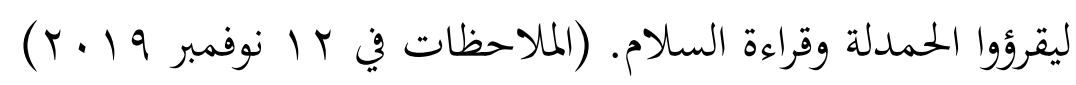

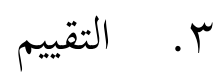

تقييم تعليم اللغة العربية للتلاميذ المعاقين ضعف البصر هو الحفظ والسؤال والإجابة. تعتبر

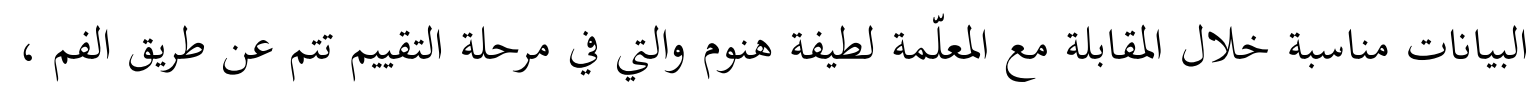

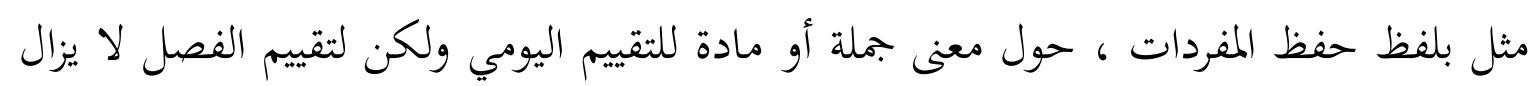

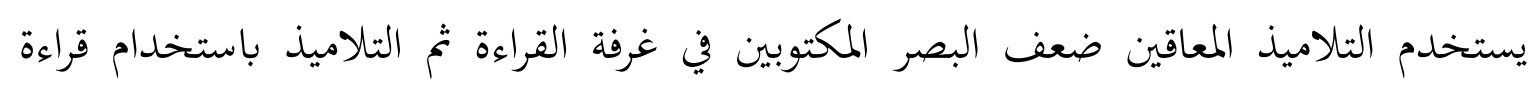

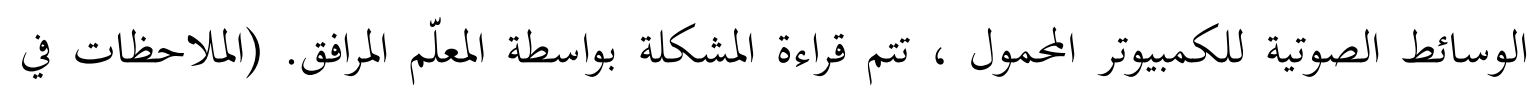

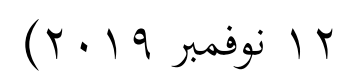
من نتائج الملاحظات والمقابلات والوثائق التي أجراها الباحثون فيما يتعلق بتنفيذ التعليم الشامل في تعليم اللغة العربية في المدرسة العالية الحكومية الإسلامية ب كلاتين بالتأكيد لديه اختلاف مع تطبيق تعليم اللغة العربية في الفصول العادية في المعلّم الأخرى. فيما يلي خطوات التعليم في الفصول الشاملة: 


\section{ا ـ التخطيط لترقية جودة العملية}

أن التخطيط لتعليم اللغة العربية من قبل المعلم في المدرسة العالية الحلكومية الإسلامية ץ كالاتين أصبح مثاليًا قدر الإمكان من خلال الانتباه إلى وضع وظروف التلاميذ العاديين وذوي الاحتياجات الخاصة. أن المعلم يعتزم تحسين جودة عملية التعليم إذا كان يبدأ بالتخطيط الجيد.

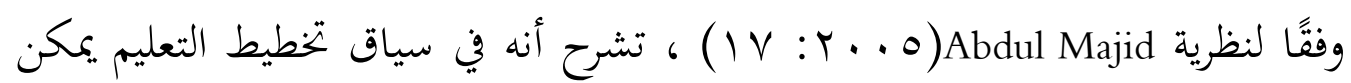
تفسيره على أنه عملية إعداد المواد التعليمية ، واستخدام الوسائط التعليمية ، واستخدام أساليب التعلم أو الأساليب ، والتقييم في موقع زمني سيتم تنفيذه في وقت معين لتحقيق الأهداف تحديدها.

في جوهرها يعد تعليم اللغة العربية في المدرسة العالية الحكومية الإسلامية ب كلاتين مثاليًا قدر الإمكان من خلال الانتباه إلى وضع وظروف التلاميذ العاديين وذوي الاحتياجات الخاصة حتى يتمكنوا من تعليم متابعة التعليم بشكل جيد عن طريق وضع (RPP) الدروس أولاً ولكن في الممارسة العملية تتكيف مع الموقف وتخصيص الوقت.

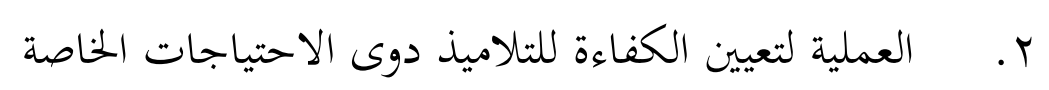

وفقًا لعرض البيانات في النقطة ب ، يوضح أن عملية تعليم التلاميذ ذوي الاحتياجات الخاصة في المدرسة العالية الحكومية الإسلامية ب كلاتين تؤدي إلى تحسن أكاديمي. يختلف التدريس في المدارس الشاملة عن التدريس في المدارس العادية حيث يأتي جميع التلاميذ. هناك حاجة إلى تعديلات المناهج الدراسية للتلاميذ ذوي الاحتياجات الخناصة الذين يرتادون المدارس العادية الشاملة لدعم التحصيل الدراسي.

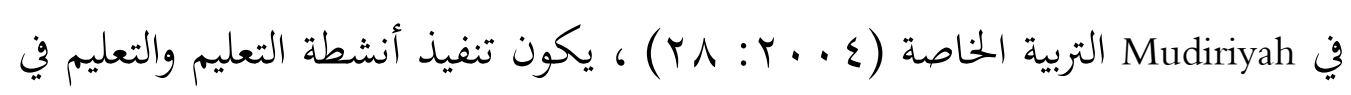
الفصول الجامعة بشكل عام هو نفسه تنفيذ أنشطة التعليم والتعليم في الفصول العادية. ومع ذلك ، لأنه في الفصول الشاملة إلى جانب التلاميذ الطبيعيين ، هناك أيضًا تلميذ ذوو احتياجات خاصة يعانون من تشوهات أو الخرافات (سواءً كانت حسية جسدية أو فكرية أو اجتماعية أو عاطفية أو عصبية) مقارنةً بالتلاميذ العاديين ، لذا في الأنشطة التي تستخدم الاستراتيجيات والوسائط والطرق يجب تعديلها مع كل اضطراب. 


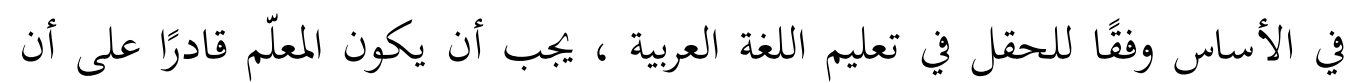
يصبح معلّما للمادة وكذلك معلّما أعمى يمكنه فهم الاختلافات بين التلاميذ العاديين والتلاميذ ذوي الاحتياجات الخاصة. r. م. التقييم لتحسين نتائج التعليم

تقييم تعليم اللغة العربية للتلاميذ المعاقين ضعف البصر هو الحفظ والسؤال والإجابة.

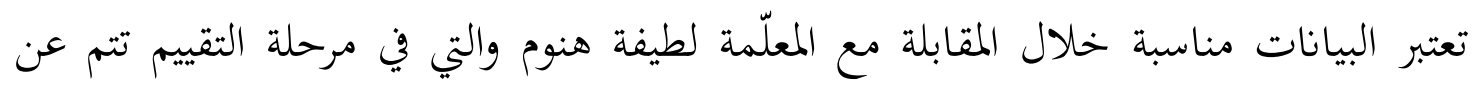
طريق الفم ، مثل لفظي حفظ المفردات ، حول معنى جملة أو مادة للتقييم اليومي ولكن لتقييم الفصل لا يزال يستخدم التلاميذ المعاقين ضعف البصر المكتوبين في غرفة القراءة ثم التلاميذ باستخدام قراءة الوسائط الصوتية للكمبيوتر المحمول ، تتم قراءة المشكلة بواسطة المعلم المرافق.

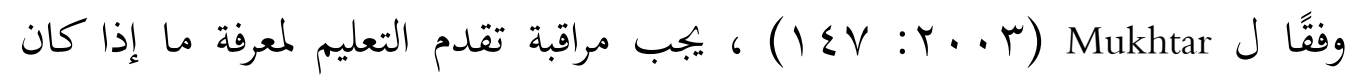

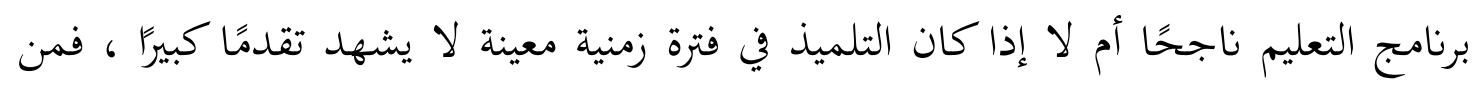
الضروري مراجعة العديد من الجوانب ذات الصلة. على العكس من ذلك ، إذا واجهه برنامج

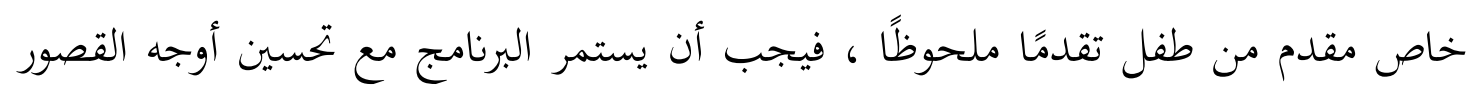
أو تحسينها.

الإختام

بناء على البحث المذكور في الباب السابق ، فتخالص الباحثة بأن تنفيذ تعليم اللغة العربية في فصول شاملة للتلاميذ المعاقين ضعف البصر للصف العاشر يدور حول التخطيط لترقية جودة العملية ، العملية لتعيين الكفاءة للتلاميذ دوى الاحتياجات الخاصة و التقييم لتحسين نتائج التعليم. التعليم

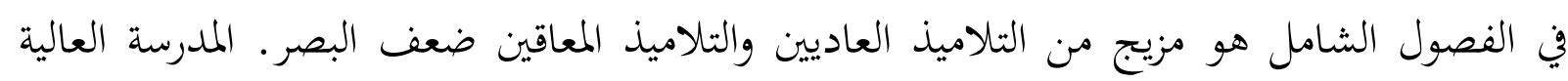

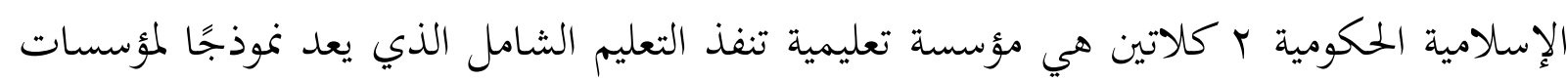

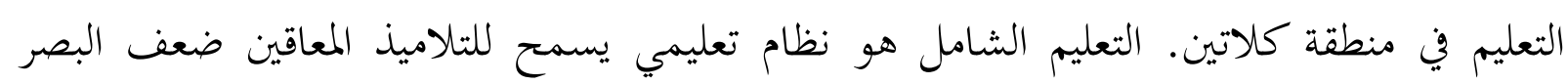

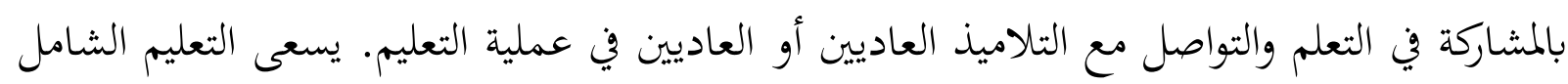

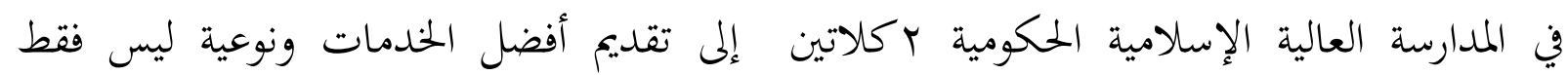
للتلاميذ العاديين ، ولكن أيضًا للتلاميذ المعاقين ضعف البصر. 


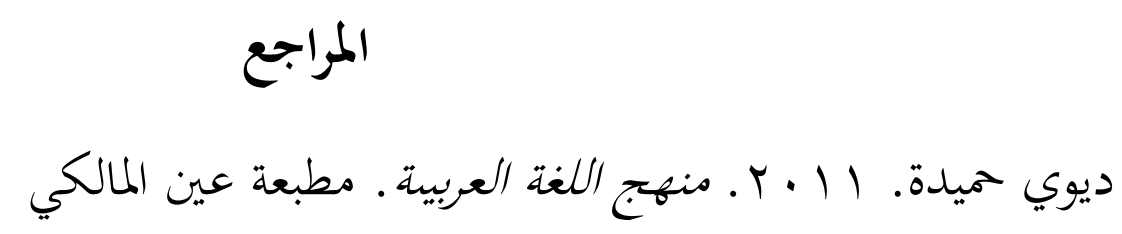

Abdul Majid. (2006). Perencanaan Pembelajaran Mengembangkan Standar Kompentensi Guru. Bndung: Remaja Rosdakarya.

Dadang Garnida. Pengantar Pendidikan Inklusif. Bandung . Refika Aditama.

Direktorat Pendidikan Luar Biasa. (2005). Pedoman Penyelenggaraan PendidikanTerpadu. Jakarta : Direktorat Pembinaan Sekolah Luar Biasa.

Jati Rinankri Atmaja. 2018. Pendidikan dan Bimbingan Anak Berkebutuhan Khusus.Bandung.

Moerdiani. 1987. Psikolog Anak Luar Biasa. Bandung . Universitas Islam Nusantara.

Mohammad Efendi. 2006. Pengantar Psikopedagogik Anak Berkelainan. Jakarta. Bumi Aksara.

Muhammad Takdir Illahi. 2016. Pendidikan Inklusif Konsep dan Aplikasinya . Yogyakarta . ArRuzz Media.

Mukhtar. (2002). Desain Pembelajaran Pendidikan Agama Islam. Jakarta : C.V. Ikapi.

Ni’matuzahrah, Yuni Nurhamida. 2016. Individu Berkebutuhan Khusus dan Pendidikan Inklusif. Malang. UMM Press.

Nyoman Surna, Olga D Pandeirot. 2014. Psikolog Pendidikan 1 . Jakarta . Erlangga.

Peraturan Menteri Pendidikan Nasional Nomor 70 tahun 2009 tentang : Pendidikan Inklusif bagi Peserta Didik yang Memiliki Kelainan dan Memiliki Potensi Kecerdasan dan Bakat Istimewa. Jakarta . Direktorat Jendral Pendidikan Dasar.

Stela Olivia. 2017 . Pendidikan Inklusif untuk Anak-anak Berkebutuhan Khusus. Yogyakarta. Andi Yogyakarta.

Sugiono . 2017 Metode Penelitian Pendidikan Pendekatan Kuantitatif, Kualitatif. Bandung . Alfabeta Bandung.

Suryosubroto. (2004). Proses Belajar Mengajar di Sekolah. Jakarta: Rineke Cipta.

Widjaya. 2013. Bentuk-bentuk Tunanetra dan Strategi Pembelajarannya. Yogyakarta . Java Litera. 